\title{
The Effect of DHF Education on DHF Prevention Knowledge of 5th and 6th Grade Students of SDN Purwotengah II Mojokerto
}

\author{
Fernanda Irfatul Laily ${ }^{1}$, Lynda Rossyanti ${ }^{2^{*}}$, Sulistiawati ${ }^{3}$
}

${ }^{1}$ Faculty of Medicine, Universitas Airlangga, Surabaya, Indonesia.

2Department of Parasitology, Faculty of Medicine, Universitas Airlangga, Surabaya, Indonesia.

${ }^{3}$ Department of Public Health and Preventive Medicine, Faculty of Medicine, Universitas Airlangga, Surabaya, Indonesia.

\section{A B S T R A C T}

Introduction: Cases of Dengue Haemorrhagic Fever (DHF) are still one of the public health diseases that are widespread in the world including tropical and subtropical regions in Indonesia. One of the factors that influence DHF is prevention of DHF education for elementary school students considering the incidence of DHF is fluctuating and has the potential to attack children.

Methods: A pre-experimental, with one group pre and post-test design. The sample of this research were 5th and 6th grade students of SDN Purwotengah II Mojokerto. There were 55 respondents with total sampling technique. Data collection was done by giving questionnaires at pretest, post-test 1 , and post-test 2 after two days of education. Data analysis used Friedman test, followed by Wilcoxon test to find out different locations.

Results: Based on Friedman test on pretest, post-test 1, and posttest 2 after two days of education, $p$ value $=0.000(p<0.05)$. Followed by Wilcoxon test at pretest with post-test $1, p$ value $=0.000(p<0.05)$ and on post-test 1 with post-test 2 after two days of education, $p$ value $=0.164(p>0.05)$.

Conclusion: There was an effect of education on the knowledge of pretest, posttest 1 and post-test 2 after two days of education for students. The effect of education on the knowledge of pretest and post-test 1 contained differences in significance, while the effect of education on post-test 1 and post-test 2 after two days of education contained no difference in significance.

(c) 2020 JUXTA: Jurnal IImiah Mahasiswa Kedokteran Universitas Airlangga. Available at https://e-journal.unair.ac.id/juxta

* Correspondence: Iyndarossyanti@gmail.com

JUXTA: Jurnal IImiah Mahasiswa Kedokteran Universitas Airlangga

p-ISSN: 1907-3623; e-ISSN: 2684-9453

DOI: $10.20473 /$ juxta.V11l22020.51-55

Open access under Creative Commons Attribution-ShareAlike 4.0 International License (CC-BY-SA)

\section{ARTICLE INFO}

\author{
Article history: \\ Received 10 June 2020 \\ Received in revised form 3 July \\ 2020
}

Accepted 13 July 2020

\author{
Keywords: \\ DHF, \\ DHF Prevention, \\ DHF Education.
}




\section{Introduction}

Dengue Haemorrhagic Fever (DHF) is a dangerous and contagious disease caused by dengue virus through transmission of mosquitoes in Aedes aegypti, Aedes albopictus, Aedes polynesiensis, and Aedes scutellaris species with the main vector of female Aedes aegypti mosquitoes. ${ }^{1}$ This disease is still one of the diseases that is widespread in the tropical and subtropical regions of the world. Including in Indonesia, in which the first DHF was discovered in 1968 in Surabaya and Jakarta. The first number of DHF sufferers was 58 people with 24 deaths (Case Fatality Rate $41.3 \%$ ). ${ }^{2}$ More than 2.5 billion people or $40 \%$ of total population in the world, around 50 million to 100 million people, are infected with the dengue virus every year with 22,000 deaths per year. ${ }^{3}$

DHF cases can attack all age including children. The incidence of DHF is increasing throughout the world and several regions in Asia have become the main causes of dangerous diseases and child mortality. ${ }^{4}$ Every year around 50 million are infected with dengue, and around 500,000 people need hospital treatment, which mostly occurs among children. ${ }^{5}$ The group of children aged 5-14 years old is the highest proportion of sufferers who experience DHF in Indonesia with $42.72 \%{ }^{6}$

The spread is widespread and infectious in various parts of Indonesia, especially in areas with high population densities, even sporadically occurring extraordinary events. Almost all districts/cities in East Java are endemic for dengue disease, including Mojokerto. According to Mojokerto Health Office, the cases of dengue from 2004 to 2006 in Mojokerto always increased and even reached outbreaks. In the case of DHF in 2007 to July 2018, 33, 27, $26,19,14,24,17,9,13,24,11$, and 9 cases. $^{7}$ The number of cases is far from EE because of the control programs that have been implemented by the government. Although it does not cause outbreaks and deaths, the people and Mojokerto government must remain vigilant about infectious diseases with a number of fluctuating events. ${ }^{8}$

Control efforts have been established by the Mayor of Mojokerto to increase the role and participation of the community on DHF barriers in the law of incidence and death. ${ }^{7,8}$ It takes participation and active role of citizens, administrators of public places or worship places, employees in offices and in schools including the education of school children in various areas of Mojokerto in implementing DHF control programs.

The school environment that does not show cleanliness is very potential in the transmission of DHF, there needs to be an increase in knowledge of prevention of dengue considering that most DHF cases have attacked children with fluctuating incidence. The right target is school, especially elementary school, because students spent the morning to afternoon at school. ${ }^{9}$ This increase in knowledge can be provided through DHF education on prevention of DHF in elementary school students in promotive and preventive efforts to maintain the health status that occurs, as to prevent the onset of disease and overcome problems that occur continuously. Based on the description above, it is necessary to conduct a study to determine the effect of DHF education on DHF prevention knowledge of 5th and 6th grade students of SDN Purwotengah II Mojokerto.

\section{Methods}

This study used a pre-experimental method with one group pre and post-test research design. The study population was students aged 10-12 years old, the 5th and 6th grade students of SDN Purwotengah II Mojokerto. The number of samples consisted of 55 respondents who used the total sampling technique. The independent variable in this study was education about prevention of dengue while the dependent variable was knowledge of prevention of dengue students in 5th and 6th grade students of SDN Purwotengah II Mojokerto and variable presence of larvae. Data was collected by giving questionnaires 20 questions at the pretest, post-test 1 , and post-test 2 after two days of education. Data analysis used Friedman test, followed by Wilcoxon Signed Ranks Test to find out the location of different measurements.

\section{Results}

Table 1. Characteristics of respondents

\begin{tabular}{lcc}
\hline & $\mathbf{f}$ & $\%$ \\
\hline Age (years) & 14 & 25.5 \\
10 & 22 & 40 \\
11 & 19 & 34.5 \\
12 & & \\
Grade & 29 & 52.7 \\
5 th & 26 & 47.3 \\
6th & & \\
Gender & 34 & 61.8 \\
Male & 21 & 38.2 \\
Female & \\
\hline
\end{tabular}

The results of this study indicate the characteristics of respondents namely students aged 11 years old and class $V$ students are the highest number of respondents, while male students were more than female students.

Table 2. Description of students' knowledge before and after education.

\begin{tabular}{|c|c|c|c|c|c|c|}
\hline \multirow[t]{2}{*}{ Knowledge } & \multicolumn{2}{|c|}{ Pretest } & \multicolumn{2}{|c|}{$\begin{array}{c}\text { Post-test } \\
1\end{array}$} & \multicolumn{2}{|c|}{$\begin{array}{c}\text { Post-test } \\
2\end{array}$} \\
\hline & $f$ & $\%$ & $f$ & $\%$ & $f$ & $\%$ \\
\hline \multicolumn{7}{|l|}{ Definition } \\
\hline 1 & 35 & 63.3 & 55 & 100 & 55 & 100 \\
\hline 2 & 53 & 96.4 & 55 & 100 & 55 & 100 \\
\hline \multicolumn{7}{|l|}{ Etiology } \\
\hline 3 & 42 & 76.4 & 55 & 100 & 53 & 96.4 \\
\hline 4 & 52 & 94.5 & 53 & 96.4 & 54 & 98.2 \\
\hline 5 & 54 & 98.2 & 46 & 83.6 & 50 & 90.9 \\
\hline 6 & 30 & 54.5 & 54 & 98.2 & 48 & 87.3 \\
\hline 7 & 51 & 92.7 & 50 & 90.9 & 47 & 85.5 \\
\hline 8 & 9 & 16.4 & 54 & 98.2 & 53 & 96.4 \\
\hline 9 & 7 & 12.7 & 52 & 94.5 & 53 & 96.4 \\
\hline 10 & 51 & 92.7 & 51 & 92.7 & 52 & 94.5 \\
\hline \multicolumn{7}{|c|}{ Symptoms and Treatment } \\
\hline 11 & 31 & 56.4 & 46 & 83.6 & 41 & 74.5 \\
\hline
\end{tabular}




\begin{tabular}{|c|c|c|c|c|c|c|}
\hline 12 & 19 & 34.5 & 31 & 56.4 & 32 & 58.2 \\
\hline 13 & 50 & 90.9 & 50 & 90.9 & 45 & 81.8 \\
\hline \multicolumn{7}{|c|}{ Prevention and Eradication } \\
\hline 14 & 5 & 9.1 & 49 & 89.1 & 47 & 85.5 \\
\hline 15 & 40 & 72.7 & 46 & 83.6 & 45 & 81.8 \\
\hline 16 & 19 & 34.5 & 47 & 85.5 & 48 & 87.3 \\
\hline 17 & 48 & 87.3 & 54 & 98.2 & 55 & 100 \\
\hline 18 & 16 & 29.1 & 48 & 87.3 & 46 & 83.6 \\
\hline 19 & 30 & 54.5 & 50 & 90.9 & 52 & 94.5 \\
\hline 20 & 26 & 47.3 & 50 & 90.9 & 48 & 87.3 \\
\hline
\end{tabular}

From the results of the pretest, it can be seen that the most correct answer was questionnaire number 2 about classification of types of diseases and number 5 about the types of mosquitoes that transmit DHF. Meanwhile, the results of the pretest with the fewest correct answers were questionnaire number 14 about the mosquito control program in Mojokerto and number 9 about the breeding site of the Aedes mosquito. After post-test 1 and post-test 2, the value of knowledge increased compared to the value of the pretest. Questionnaire number 12 regarding the appropriate treatment for DHF patients was the least number of answers from post-test 1 and post-test 2 .

Table 3. Distribution of mean and median values.

\begin{tabular}{ccccc}
\hline & N & Mean & $\begin{array}{c}\text { Std. } \\
\text { Deviation }\end{array}$ & $\begin{array}{c}\text { Median } \\
\text { (Maximum- } \\
\text { Minimum) }\end{array}$ \\
\hline Pretest & 55 & 12.15 & 2.26 & $12(16-7)$ \\
Post-test 1 & 55 & 18.11 & 1.45 & $18(20-13)$ \\
Post-test 2 & 55 & 17.80 & 1.90 & $18(20-13)$ \\
\hline
\end{tabular}

The average value of post-test 1 and post-test 2 knowledge after being educated had a higher value compared to the value of the pretest before education.

Table 4. Friedman test results of pretest, post-test 1, and post-test 2.

\begin{tabular}{cccc}
\hline \multirow{2}{*}{ Variable } & \multicolumn{3}{c}{ Knowledge } \\
\cline { 2 - 4 } & Pretest & Post-test 1 & Post-test \\
& 55 & 55 & 55 \\
\hline $\mathrm{N}$ & 5 & 0.000 & \\
P Value. & &
\end{tabular}

Nonparametric results with Friedman test obtained a value of $p=0.000$. Because the value of $p<0.05$, it can be concluded that there are differences in the value of students' knowledge.

Table 5. The results of Wilcoxon signed rank tests for pretest, post-test 1, and post-test 2 .

\begin{tabular}{ccccc}
\hline Knowledge & N & $\begin{array}{c}\text { Negative } \\
\text { Ranks }\end{array}$ & Ties & $\begin{array}{c}\text { Positive } \\
\text { Ranks }\end{array}$ \\
\hline $\begin{array}{c}\text { Pretest-Post-test 1 } \\
\text { P Value }\end{array}$ & 55 & 0 & 0 & 55 \\
\hline $\begin{array}{c}\text { Posttest 1-Post-test 2 } \\
\text { P Value }\end{array}$ & 55 & 19 & $\begin{array}{c}14 \\
0\end{array}$ & 22 \\
\hline
\end{tabular}

Obtained significance value of $p=0.000$ means $p<$ 0.05 can be concluded that there are significant differences in knowledge between the results before education and after education. Significance value obtained $p=0.164$ which has $p>0.05$, thus it can be concluded that there is no significant difference between knowledge after education and knowledge two days after education.

\section{Discussion}

In this study, based on the characteristics, age and gender are part of the characteristics that can be associated with knowledge and behavior of prevention of DHF. ${ }^{10}$ According to Saraswati and Mulyantari, the 6-11 years age group is the highest incidence of DHF. ${ }^{11}$ According to Nisalak, et al., the 5-9 years age group represents the highest proportion of cases affected. Children aged 5-14 years old are the highest incidence of dengue cases per 100,000 inhabitants. ${ }^{12,13}$ The prevalence of dengue cases for children under 15 years old is higher when compared to those above 15 years old. ${ }^{14}$ Based on gender, male and female have the same chance of getting DHF. According to research by Chamidah, there is a difference in the incidence of dengue based on sex, in which male has a higher incidence rate. ${ }^{15}$

School has become one of public places that has high potential in the breeding of Aedes mosquitoes with the target mostly school children. Active Aedes aegypti mosquitoes suck blood in the morning until the evening. ${ }^{16}$ Efforts to eliminate infectious diseases have increased. Health and education interventions can complement each other because good education promotes skills, values, and attitudes that lead to a healthy life. ${ }^{17}$ Health education is an effort to encourage the empowerment of individuals and communities in determining the success of prevention of DHF. ${ }^{18}$ Debriefing knowledge of prevention of DHF for students is needed in improving prevention efforts that can reduce the incidence of DHF.

Based on the value of the questionnaire, the results of the pretest with the most correct answers were questionnaire number 2 about classification of types of diseases and number 5 about the types of mosquitoes that transmit dengue. Based on the interview, this high level of knowledge was influenced by the habit of students watching cartoons and news broadcasts that wrote about DHF, also from environmental information around the house, or having experienced dengue fever. Meanwhile, the results of the pretest with the fewest correct answers were questionnaire number 14 about the mosquito control program in Mojokerto and number 9 about the breeding site of the Aedes mosquito. Public awareness about the prevention of mosquito bites and control of mosquito breeding sites is very important. ${ }^{19}$ Meanwhile, the results of post-test 1 and post-test 2 values increased compared to the value of the pretest. Questionnaire number 12 on the proper handling of DHF patients was a questionnaire with the fewest answers from post-test 1 and post-test 2 . This requires special attention with the authorities to increase knowledge about efforts to deal with DHF appropriately. Respondents with knowledge of the right handling of DHF can prevent the death of DHF. In the study of Egedus, et al., the education level of respondents on symptoms, 
prevention, and danger of dengue fever still showed poor results. ${ }^{20}$

The results of the analysis using Friedman test to determine the effect of DHF education on knowledge of prevention of DHF students showed there are differences in the value of students' knowledge. To find out groups with different meanings, the analysis of follow-up tests used Wilcoxon Signed Ranks Test in this study. From the results of Wilcoxon test, the value of the pretest and post-test 1 showed there was a significant difference in knowledge between the results before education and after education. In the research of Hernandez, et al., the results of the postintervention questionnaire showed a significant increase in the level of knowledge. ${ }^{21}$ The average score of total knowledge will increase from the results of the pretest to post-test. ${ }^{22,}{ }^{23}$ Meanwhile, the results of Wilcoxon Test of post-test 1 and post-test 2 values did not have a significant difference between knowledge after education and knowledge two days after education. This result is the same as that of Cleeren, et al., who also gave post-test 2 as a follow-up test to determine knowledge retention after 2 weeks of intervention. The results of the study showed that the average post-test score was better than the follow-up test. ${ }^{24,} 25$ This requires repeated or more than 1 time education to increase the retention of post-test 2 values.

\section{Conclusion}

There was an effect of education on the knowledge of pretest, post-test 1, and post-test 2 after two days of education for students. The effect of education on the knowledge of pretest and post-test 1 contained differences in significance, while the effect of education on post-test 1 and post-test 2 after two days of education contained no difference in significance.

\section{CONFLICT OF INTEREST}

The author stated there is no conflict of interest in this study.

\section{REFERENCES}

1. Sudjana P. Diagnosis Dini Penderita Demam Berdarah Dengue Dewasa. Buletin Jendela Epidemiologi. 2010; 2 : 21-5.

2. Indonesia KKR. Demam Berdarah Dengue di Indonesia Tahun 1968-2009. Buletin Jendela Epidemiologi. 2010; 2. 3. Knowlton K, Solomon G and Rotkin-Ellman M. "Fever Pitch: Mosquito-Borne Threat Spreading in the Americas". New York: Natural Resources Defense Council, 2009.

4. Organization WH. Dengue and Severe Dengue. Geneva: World Health Organization, 2003.

5. Organization WH. Dengue and Severe Dengue : Distribution Trends. Geneva: World Health Organization, 2018.

6. Indonesia KKR. Penderita DBD Tertinggi pada Anak Sekolah. Jakarta: Kementerian Kesehatan Republik Indonesia, 2016

7. Mojokerto DKK. Profil Kesehatan Kota Mojokerto Tahun 2007. Mojokerto: Dinas Kesehatan Kota Mojokerto, 2007.
8. Mojokerto DKK. Profil Kesehatan Kota Mojokerto Tahun 2018. Mojokerto: Dinas Kesehatan Kota Mojokerto, 2018.

9. Indonesia KKR. Menkes dan Mendikbud Bersepakat Sekolah Tempat Pembelajaran Hidup Sehat. Jakarta: Kementerian Kesehatan Republik Indonesia, 2015.

10. Rakhmani AN, Limpanont $\mathrm{Y}$, Kaewkungwal J and Okanurak K. Factors Associated with Dengue Prevention Behaviour in Lowokwaru, Malang, Indonesia: A CrossSectional Study. BMC Public Health. 2018; 18: 619.

11. Citta Saraswati LP and Mulyantari NK. Prevalensi Demam Berdarah Dengue (DBD) Primer dan Sekunder Berdasarkan Hasil Pemeriksaan Serologis di Rumah Sakit Balimed Denpasar. E-Jurnal Medika Udayana. 2017; 6. 12. Nisalak A, Clapham HE, Kalayanarooj S, et al. Forty Years of Dengue Surveillance at a Tertiary Pediatric Hospital in Bangkok, Thailand, 1973-2012. The American Journal of Tropical Medicine and Hygiene. 2016; 94: 1342-

13. Bravo L, Roque VG, Brett J, Dizon R and L'Azou M. Epidemiology of Dengue Disease in the Philippines (20002011): A Systematic Literature Review. PLoS Negl Trop Dis. 2014; 8: e3027-e.

14. Dias JJJ, Branco M, Queiroz RCS, Santos AMD, Moreira EPB and Silva M. Analysis of Dengue Cases according to Clinical Severity, São Luís, Maranhão, Brazil. Revista do Instituto de Medicina Tropical de Sao Paulo. 2017; 59: e71.

15. Chamidah D. Prevalensi Dengue pada Mahasiswa Universitas Surabaya. Jurnal IImiah Kedokteran Wijaya Kusuma. 2019; 6: 45-8.

16. Trisnawati AG and Rahayuningsih FB. Analisis Faktor Risiko Kejadian Demam Berdarah Dengue di Desa Mojosongo Kabupaten Boyolali. 2010.

17. Pradhan E, Suzuki EM, Martínez S, Schäferhoff M and Jamison T. The Effects of Education Quantity and Quality on Child and Adult Mortality: Their Magnitude and Their Value. In: Bundy DAP, Silva ND, Horton S, Jamison DT and Patton GC, (eds.). Child and Adolescent Health and Development. Washington (DC): The International Bank for Reconstruction and Development / The World Bank (c) 2017 International Bank for Reconstruction and Development / The World Bank., 2017.

18. Frank AL, Beales ER, de Wildt G, Meza Sanchez G and Jones LL. "We need people to collaborate together against this disease": A Qualitative Exploration of Perceptions of Dengue Fever Control in Caregivers' of Children under 5 Years, in the Peruvian Amazon. PLoS Negl Trop Dis. 2017; 11: e0005755.

19. Egedus VL, Ortega JM and Obando AA. Knowledge, Perceptions, and Practices with Respect to the Prevention of Dengue in a mid-Pacific Coastal Village of Costa Rica. Revista de Biologia Tropical. 2014; 62: 859-67.

20. Elsinga J, Schmidt M, Lizarazo EF, et al. Knowledge, Attitudes, and Preventive Practices Regarding Dengue in Maracay, Venezuela. The American Journal of Tropical Medicine and Hygiene. 2018; 99: 195-203.

21. Hernández Pérez MC, Díaz-Gómez NM, Romero Manzano AM, Díaz Gómez JM, Rodríguez Pérez V and Jiménez Sosa A. [Effectiveness of an Intervention to Improve Breastfeeding Knowledge and Attitudes among Adolescents]. Revista Espanola de Salud Publica. 2018; 92.

22. El Seifi OS, Mortada EM and Abdo NM. Effect of Community-Based Intervention on Knowledge, Attitude, and Self-Efficacy toward Home Injuries among Egyptian Rural Mothers Having Preschool Children. PloS one. 2018; 13: e0198964.

23. Charzyńska-Gula M, Sygit K, Sygit M, Goździewska M, Dobrowolska B and Gałęziowska E. Problems of Health 
Education in Rural Areas in Poland. Ann Agric Environ Med. 2013; 20: 515-22.

24. Cleeren G, Quirynen M, Ozcelik O and Teughels W Role of 3D Animation in Periodontal Patient Education: A Randomized Controlled Trial. Journal of Clinical Periodontology. 2014; 41: 38-45.
25. Pande S, Pande S, Parate V, Pande S and Sukhsohale N. Evaluation of Retention of Knowledge and Skills Imparted to First-Year Medical Students through Basic Life Support Training. Advances in Physiology Education. 2014; 38: 42-5. 